\author{
Contents list available at Multidisciplinary Journal website \\ Multidisciplinary Journal \\ Journal homepage: https://jurnal.unej.ac.id/index.php/multijournal
}

\title{
Analisis Kebijakan dan Kepimpinan Keselamatan dan Kesehatan Kerja pada Kejadian Kecelakaan Kerja di Rumah Sakit Umum X Kabupaten Y
}

\author{
Analysis of Policy and Leader Work Health and Safety on Accident Work in Hospital X Regency Y \\ Ekin Akhsa Febriandini ${ }^{1, *}$, Sri Hernawati ${ }^{2}$, Isa Ma'rufi ${ }^{3}$ \\ ${ }_{1,2,3}$ Program Studi Ilmu Kesehatan Masyarakat, Program Pascasarjana, Universitas Jember \\ Email*: ekin.akhsa@gmail.com
}

\begin{abstract}
The regulation of Manpower no 5 Year 1996 on Safety Management System and Occupational Health Article 3 explains several points including the policy establishment for Safety Management System and Occupational Health. The commitment and the policy in the work place should be reviewed repeatedly and regularly. The recurring and regular review are expected to improve the performance of Safety and Occupational Health in the work place. This research aims at analyzing the policy and the leadership in K3 (Safety and Occupational Health) on Occupational Accident in X Hospital in Y Regency. The methodology includes quantitative analysis employing cross sectional research design. The data were collected by questionnaires. This research uses Chi Square with significance of 0,05 or $a=95 \%$. Sampling consists of 83 respondents. The finding indicates that there is no correlation between the policy and the leadership in Safety and Occupational Health with Occupational Accident in X General Hospital in Y Regency. The hospital management should concerns more on constructing and developing Safety and Occupational Health Unit in the hospital.
\end{abstract}

Keywords: policy, leadership, safety and occupational health, occupational accident, hospital

ABSTRAK. Peraturan Menteri Tenaga Kerja nomor 5 tahun 1996 tentang Sistem Manajemen Keselamatan dan Kesehatan Kerja pasal 3 menjelaskan beberapa hal yang perlu dilaksanakan, salah satunya yakni penetapan kebijakan keselamatan dan kesehatan kerja dan menjamin komitmen terhadap penerapan Sistem Manajemen Keselamatan dan Kesehatan Kerja. Komitmen dan kebijakan di tempat kerja harus ditinjau ulang secara berulang dan teratur. Kegiatan peninjauan ulang yang dilaksanakan teratur diharapkan dapat meningkatkan kinerja Keselamatan dan Kesehatan Kerja di tempat kerja. Tujuan dari penelitian ini untuk Menganalisis Kebijakan dan Kepemimpinan K3 pada kejadian kecelakaan kerja di Rumah Sakit Umum X Kabupaten Y. Metode penelitian ini menggunakan analitik kuantitatif dengan desain penelitian cross sectional. Pengumpulan data melalui pengisian angket. Uji dalam penelitian ini adalah Chi Square dengan signifikansi 0,05 atau $a=95 \%$. Jumlah sampel sebanyak 83 responden. Hasil penelitian menyatakan jika tidak ada hubungan antara kebijakan dan kepemimpinan keselamatan dan kesehatan kerja dengan kejadian kecelakaan kerja di Rumah Sakit umum X Kabupaten Y. Saran yang perlu dipertimbangkan oleh pihak manajemen rumah sakit yakni pembentukan Instalasi Keselamatan dan Kesehatan Kerja Rumah Sakit.

Kata Kunci: kebijakan, kepemimpinan, keselamatan dan kesehatan kerja, kejadian kecelakaan kerja, rumah sakit.

\section{Pendahuluan}

Pelaksanaan keselamatan dan kesehatan kerja dalam suatu organisasi biasanya dikenal dengan Sistem Manajemen Keselamatan dan Kesehatan Kerja. Sistem Manajemen Keselamatan dan Kesehatan Kerja di lingkungan kerja merupakan bagian dari sistem manajemen secara keseluruhan yang meliputi struktur organisasi, perencanaan, tanggungjawab, pelaksanaan, prosedur proses dan sumberdaya yang dibutuhkan bagi pengembangan, penerapan, pencapaian, pengkajian dan pemeliharaan kebijkan keselamatan dan kesehatan kerja dalam rangka pengendalian resiko yang berkaitan dengan kegiatan kerja guna terciptanya tempat kerja yang aman dan produktif [1].

Berdasarkan [1] tentang Sistem Manajemen Keselamatan dan Kesehatan Kerja pasal 3 menjelaskan beberapa hal yang perlu dilaksanakan, salah satunya yakni penetapan kebijakan keselamatan dan kesehatan kerja dan menjamin komitmen terhadap penerapan Sistem Manajemen Keselamatan dan Kesehatan Kerja. Komitmen dan kebijakan di tempat kerja harus ditinjau ulang secara berulang dan teratur. Kebijakan yang dilaksanakan harus melalui proses konsultasi pengurus dan wakil tenaga kerja yang nantinya hasil tersebut disebarluaskan kepada semua tenaga kerja di 
tempat kerja tersebut. peninjauan awal kondisi keselamatan dan kesehatan kerja dilakukan dengan cara : mengidentifikasi kondisi yang ada dengan ketentuan pedoman, mengidentifikasi sumber bahaya, penilaian tingkat pengetahuan, pemenuhan peraturan perundangan dan standar keselamatan dan kesehatan kerja, membandingkan penerapan keselamatan dan kesehatan kerja dengan perusahaan dan sektor lain yang lebih baik, meninjau sebab dan akibat kejadian yang mem-bahayakan, kompensasi dan gangguan serta hasil penilaian sebelumnya yang berkaitan dengan kesela-matan dan kesehatan kerja dan menilai efisiensi dan efektifitas sumberdaya yang disediakan. Kegiatan peninjauan ulang yang dilaksanakan teratur diharapkan dapat meningkatkan kinerja K3 di tempat kerja.

SMK3 wajib dilaksanakan pada setiap perusahaan atau tempat kerja dengan ketentuan tempat kerja memperkerjakan pekerja atau buruh paling sedikit 100 orang dan mempunyai potensi bahaya yang tinggi [2]. Rumah Sakit Umum X wajib melaksanakan SMK3 dikarenkan tenaga kerja yang dimiliki sudah melebihi 100 tenaga kerja yakni 604 orang dan memiliki faktor-faktor bahaya yang tinggi seperti faktor biologi, kimia, mekanik, biomekanik dan sosial psikologis [3]. Salah satu bahaya yang masih dianggap tidak terlalu berbahaya yakni faktor sosial psikologis. Faktor sosial psikologis yang terdapat di rumah sakit yakni stres kerja, beban kerja, bullying, kekerasan dan penyalahhgunaan obat-obat terlarang. Akibat yang dihasilkan bahaya psiko sosial tersebut yakni depresi, absen saat jam kerja, antisosial dan luka pada bagian tubuh.

Pelayanan K3RS harus dilaksanakan secara terpadu melibatkan berbagai komponen yang ada di rumah sakit. Pelayanan K3RS sampai saat ini dirasa-kan belum maksimal. Hal ini dikarenakan masih ban-yak rumah sakit yang belum menerapkan Sistem Ma-najemen Kesehatan dan Keselamatan Kerja [4]. Sis-tem Manajemen Kesehatan dan Keselamatan Kerja merupakan sesuatu yang baru dan menjadi sasaran penilaian akreditasi rumah sakit. Selain itu SMK3 merupakan faktor yang secara tidak langsung berhubungan dengan pasien, tetapi memegang peran penting dalam pelayanan rumah sakit. Pelayanan ru-mah sakit diharapkan memperhatikan keamanan dan keselamatan pasien maupun karyawannya. Tujuan dari penelitian ini untuk Menganalisis Kebijakan dan Kepemimpinan K3 pada kejadian kecelakaan kerja di Rumah Sakit Umum X Kabupaten Y

\section{Bahan dan Metode}

Jenis penelitian yang digunakan dalam penelitian ini adalah penelitian analitik dengan pendekatan kuantitatif dan berdasarkan waktu penelitiannya, penelitian ini termasuk penelitian cross sectional. Objek dalam penelitian ini adalah seluruh tenga kerja di Rumah Sakit Umum X Kabupaten Y. Jumlah objek sebanyak 83 responden dengan menggunakan metode Cluster Sampling dengan metode Proporsional Sampling. Penelitian ini menggunakan teknik pengumpulan data primer, yakni wawancara responden. Untuk teknik analisis data menggunakan uji chi square signifikansi 0,05 atau $\mathrm{a}=95 \%$.

\section{Hasil dan Pembahasan}

Kebijakan dan Kepemimpinan Sistem Manajemen Keselamatan Dan Kesehatan Kerja pada Kecelakaan Kerja

Tabel 1. Distribusi Kebijakan dan Kepemimpinan Keselamatan Dan Kesehatan Kerja

\begin{tabular}{llll}
\hline No & Kelompok Penerapan & Frekuensi & $\%$ \\
& & & \\
\hline 1. & Penerapan kurang & 44 & 53 \\
2. & Penerapan baik & 2 & 2 \\
3. & Penerapan memuaskan & 37 & 45 \\
\hline \multicolumn{7}{l}{ Total } & & 83 & \multicolumn{2}{l}{100} \\
\hline \multicolumn{5}{r}{ Pada tabel 1 distribusi } & kebijakan & dan
\end{tabular}

kepemimpinan keselamatan dan kesehatan kerja diketahui bahwa sebagian besar responden menjawab penerapan kurang sebanyak 44 orang (53\%). Sebanyak 2 orang $(2 \%)$ menyatakan penerapan baik dan sebanyak 37 orang (45\%) menyatakan penerapan memuaskan.

Tabel 2. Kebijakan dan Kepemimpinan Keselamatan Dan Kesehatan Kerja pada Kejadian Kecelakaan Kerja

\begin{tabular}{lllllll}
\hline No. & Kategori & \multicolumn{3}{l}{ Kecelakaan Kerja } & \multirow{2}{*}{\begin{tabular}{c} 
Total \\
\cline { 3 - 5 }
\end{tabular}} & \multicolumn{2}{l}{ Tidak } & Ya & \\
\cline { 2 - 5 } & $\mathrm{n}$ & $\%$ & $\mathrm{n}$ & $\%$ & \\
\hline 1. & $\begin{array}{l}\text { Penerapan } \\
\text { kurang }\end{array}$ & 43 & 97,7 & 1 & 2,3 & 100 \\
\hline 2. & $\begin{array}{l}\text { Penerapan } \\
\text { baik }\end{array}$ & 2 & 100 & 0 & 2 & 100 \\
\hline 3. & $\begin{array}{l}\text { Penerapan } \\
\text { memuaskan }\end{array}$ & 32 & 86,5 & 5 & 13,5 & 100 \\
\hline
\end{tabular}

Pada tabel 2 mengenai kebijakan dan kepemimpinan keselamatan dan kesehatan kerja dengan Kejadian Kecelakaan Kerja, diketahui jika responden yang memberi pernyataan jika penerapan kebijakan dan kepemimpinan keselamatan dan kesehatan kerja memuaskan sebanyak 5 orang $(13,5 \%)$ dan penerapan baik sebanyak 1 orang $(2,3 \%)$.

Tabel 3. Hubungan Kebijakan dan Kepemimpinan Keselamatan Dan Kesehatan Kerja pada Kejadian Kecelakaan Kerja

\begin{tabular}{lc}
\hline Hubungan Variabel & Chi-Square Correlation \\
\hline Kebijakan dan & 0,0084 \\
Kepemimpinan & \\
Keselamatan dan & \\
Kesehatan Kerja pada & \\
Kecelakaan Kerja & \\
\hline Untuk mengetahui ada tidaknya hubungan an-tara
\end{tabular}
kebijakan dan kepemimpinan Keselamatan dan Kesehatan Kerja pada Kejadian Kecelakaan Kerja dil-akukan analisis data menggunakan uji chi square dengan $\alpha=0,05$. Berdasarkan analisis data didapat-kan hasil bahwa tidak ada hubungan antara Kebijakan dan Kepemimpinan Sistem Manajemen Keselamatan dan Kesehatan Kerja pada Kejadian Kecelakaan Kerja dikarenakan hasil uji chi square yakni $\mathrm{p}=0,084$ yang lebih besar daripada $\alpha=0,05$. 
Distrubusi kebijakan dan kepemimpinan didapatkan kebijakan keselamatan dan kesehatan kerja dan kepemimpinan dengan Kejadian Kecelakaan Kerja, diketahui bahwa sebagian besar responden menjawab penerapan kurang. Hal yang mendasari sebagian besar responden menyatakan jika penera-pan kurang yakni sejauh ini masih belum ada ke-bijakan yang dibuat khusus mengenai keselamatan dan kesehatan kerja dan untuk Panitia Pelaksana keselamatan dan kesehatan kerja sudah dibentuk dan disahkan oleh Direktur Rumah Sakit Umum X Kabu-paten Y akan tetapi masih belum ada penginformasian kepada seluruh karyawan. Kebijakan sangat penting dan menjadi landasan utama dalam suatu organisasi yang diharapkan dapat menggerakkan se-luruh elemen yang ada didalamnya sehingga program keselamatan dan kesehatan kerja yang diharapkan dapat berjalan dengan baik, salah satu contoh pro-gram keselamatan dan kesehatan kerja yang diinginkan berhasil yakni dengan tidak adanya kejadian kecelakaan kerja dan penyakit akibat kerja di tempat kerja. [5]

Hasil penelitian ini tidak sejalan dengan hasil penelitian [6] menyatakan jika dengan penerapan kebijakaan dan kepemimpinan keselamatan dan kesehatan kerja yang baik di MPS KUD Tani dapat melindungi karyawannya baik dari kecelakaan maupun penyakit akibat kerja, hal ini dapat dibuktikan dengan selalu diraihnya penghargaan zero accident sejak ta-hun 2003 sampai tahun 2011 [6]. Hasil penelitian ini menyatakan jika tidak ada hubungan antara penera-pan kebijakan K3 dan kepemimpinan dengan Kejadi-an Kecelakaan Kerja. Hal ini disebabkan angka ke-jadian kecelakaan kerja yang ditemukan sebanyak 6 kejadian yang jika kita tinjau lebih dalam mengenai fungsi dari kebijakan keselamatan dan kesehatan kerja yakni perwujudan dari komitmen pucuk pimpinan yang membuat visi dan misi, komitmen untuk melaksanakan keselamatan dan kesehatan kerja, kerangka dan program kerja. Kebijakan K3 merupa-kan roh dari sistem keselamatan dan kesehatan kerja, tanpa adanya penerapan kebijakan K3 yang baik maka penerapan SMK3 di Rumah Sakit Umum X Ka-bupaten Y tidak dapat mencapai tujuan zero accident di tempat kerja dan semestinya 6 angka kejadian ke-celakaan kerja merupakan angka yang cukup besar yang dapat memberi dampak kerugian materi, waktu, dll.

Kebijakan K3 dan kepemimpinan dalam pelaksanaan K3 rumah sakit sudah berjalan tetapi kurang maksimal, hal tersebut yang didasari pola fikir karyawan bahwa SMK3 bukan hal yang mendesak untuk dilaksanakan di rumah sakit karena tidak menganggu pelaksanaan kerja karyawan sehari-hari. Kebijakan dan kepimpinan di Rumah Sakit Umum X masih belum nampak maksmimal dalam pelaksanaan SMK3RS hal ini dapat dilihat dari tidak ada tindak lanjut dari pembentukan P2K3. Di tempat kerja diharapkan adanya interaksi antara pucuk pimpinan dan karyawan dalam melaksanakan komitmen K3 secara terus menerus dan memastikan jika SMK3 berjalan dengan baik, pucuk pimpinan menanggapi kendala yang dialami oleh karyawan mengenai keselamatan dan kesehatannya dalam bekerja dan karyawan menaati peraturan yang telah di tetapkan oleh pucuk pimpinan dalam rangka pelaksanaan SMK3RS.

Kebijakan dan kepemimpinan K3 yang tidak memiliki hubungan dengan kejadian kecelakaan kerja disebabkan karena karyawan RSU X Kabupaten Y berfikir jika dengan adanya kebijakan Direktur rumah sakit membentuk tim P2K3 sudah cukup dalam men-erapkan K3 di rumah sakit akan tetapi jika kita pahami lebih dalam lagi penerapan kebijakan dan kepem-impinan K3 tidak hanya sampai pembentukan tim P2K3 saja, pembentukan tim P2K3 seharusnya disebarluaskan kepada seluruh tenaga kerja dan pembentukan penanggungjawab K3 di setiap ruang sehingga memudahkan komunikasi terkait $\mathrm{K} 3$ dan sistem pelaporan juga lebih terstruktur. Sejauh ini pembentukan tim P2K3 belum disebarluaskan kepada seluruh tenaga kerja sehingga tenaga kerja masih be-lum mengetahui siapa saja yang menjadi tim P2K3 dan juga masih belum adanya pembentukan pe-nanggungjawab K3 di setiap ruang sehingga komu-nikasi K3 kurang berjalan dengan baik dan juga tidak ada sistem pelaporan kejadian kecelakaan kerja di setiap ruang. Berdasarkan hasil observasi peneliti, sejauh ini pencatatan kejadian kecelakaan kerja hanya dilakukan oleh PPNI RSU X Kabupaten Y yang rata-rata dilaporkan kejadian tertusuk jarum sedangkan untuk kejadian kecelakaan kerja yang lain belum ada sistem pelaporan yang terstruktur dan tidak menutup kemungkinan jika tenaga kerja pernah mengalami ke-jadian kecelakaan kerja tetapi tidak melaporakan dikarenakan kurangnya informasi mengenai sistem pelaporan kejadian kecelakaan kerja sehingga kurangnya data mengenai kejadian kecelakaan kerja di RSU X.

\section{Kesimpulan}

Berdasarkan hasil penelitian yang telah dilaksankaan diketahui jika Kebijakan dan Kepemimpinan Sistem Manajemen Keselamatan dan Kesehatan Kerja tidak memiliki hubungan dengan kejadian kecelakaan kerja di Rumah Sakit Umum X Kabupaten Y dikarenakan ( $p$ $=0,084)$. Berdasarkan kesimpulan diatas, saran yang perlu dipertimbangkan oleh pihak manajemen dalam kaitannya dengan kebijakan dan kepemimpinan Keselamatan Dan Kesehatan Kerja dengan kejadian kecelakaan kerja antara lain:

a. Pembentukan Instalasi K3RS

b. Pengkomunikasian kebijakan K3 kepada seluruh tenaga kerja oleh pihak manajemen Rumah Sakit Umum X Kabupaten Y

c. Pembuatan manual Sistem Manajemen Keselamatan Dan Kesehatan Kerja sebagai satu bukti komitmen pimpinan dalam melaksanakan SMK3 di Rumah Sakit.

d. Pembuatan laporan rutin yang di laporkan kepada tim P2K3 dan disebarluaskan kepada seluruh tenaga kerja di Rumah Sakit Umum X Kabupaten Y

e. Dalam hal memeriksa kesesuaian kegiatan perencanaan dan untuk menentukan efektifitas kegiatan maka diadakan audit internal Sistem Manajemen Keselamatan Dan Kesehatan Kerja yang terjadwal. 


\section{Referensi}

[1] Peraturan Menteri Tenaga Kerja No.: PER.05/MEN/1996. Sistem Manajemen Keselamatan dan Kesehatan Kerja. Jakarta. Kemenakertrans

[2] Peraturan Pemerintah Republik Indonesia Nomor 50 Tahun 2012. Penerapan Sistem Manajemen Keselamatan dan Kesehatan Kerja. Jakarta: Kementrian Sekretariat Negara RI.

[3] Bennet. 1995. Manajemen Keselamatan dan Kesehatan Kerja. Jakarta: Bina Rupa Aksara.

[4] Sucipto. 2014. Keselamatan dan Kesehatan Kerja .Tangerang : Gosyen Publishing

[5] Ramli. 2010. Sistem Manajemen Keselamatan dan Kesehatan Kerja OHSAS 18001.Jakarta : Dian Rakyat.

[6] Zulyanti, N. R., 2013. Komitmen Kebijakan Keselamatan Dan Kesehatan Kerja (K3) Sebagai Upaya Perlindungan Terhadap Tenaga Kerja (Sudi pada Mitra Produksi Sigaret (MPS) KUD Tani Mulyo Lamongan). Jurnal Administrasi Publik. Program Magister Administrasi Fakultas Ilmu Sosial dan Ilmu Politik Universitas 17 Agustus 1945 : Surabaya. 